
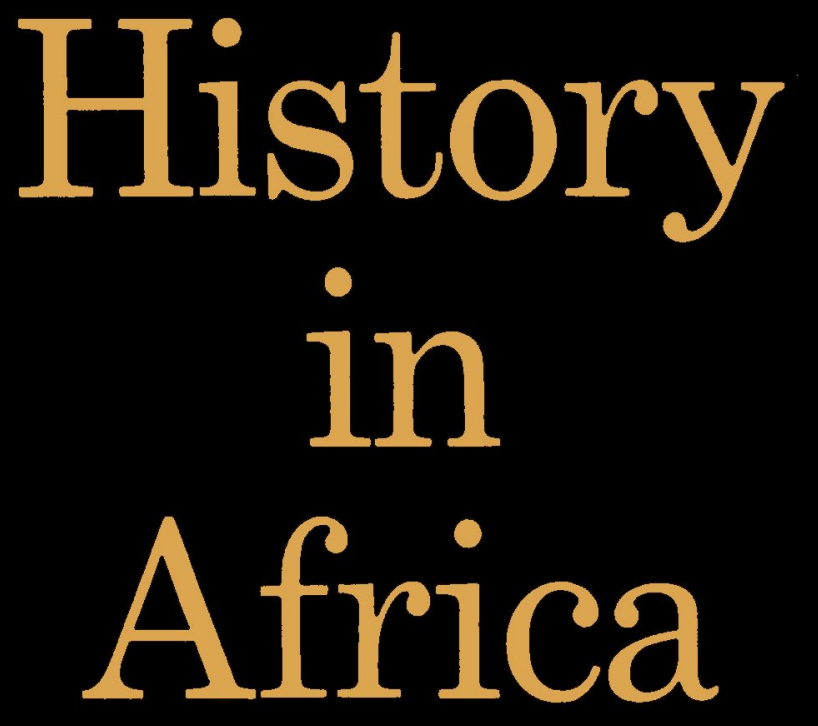

\title{
A JOURNAL OF METHOD
}

\section{David Henige, Editor}

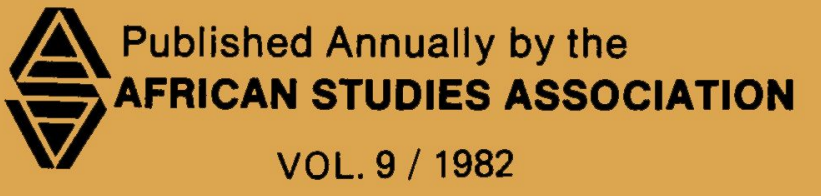




\title{
HISTORY IN AFRICA
}

\author{
EDITORIAL BOARD
}

A. E. Afigbo (University of Nigeria, Nsukka)

P. D. Curtin (Johns Hopkins University)

J. D. Fage (University of Birmingham)

P. E. H. Hair (University of Liverpool)

$\dagger$ D. H. Jones (University of London)

R. C. C. Law (University of Stirling)

J. C. Miller (University of Virginia)

A. D. Roberts (University of London)

A. Teixeira da Mota (Lisbon)

M. Twaddle (University of London)

A. van Dantzig (University of Ghana)

J. Vansina (University of Wisconsin, Madison)

C. C. Wrigley (University of Sussex)

History in Africa is published annually by the African Studies Association. Permission to reproduce materials from History in Africa should be obtained from the African Studies Association. Subscriptions and other business correspondence should be sent to the African Studies Association, Epstein Building, Brandeis University, Waltham, Massachusetts 02154 , U.S.A. Manuscript and other editorial correspondence should be sent to David Henige, Memorial Library, University of Wisconsin, Madison, Wisconsin 53706, U.S.A.

Articles in History in Africa represent neither the views of the African Studies Association nor those of its officers. The editor is responsible for the final selection of the content of History in Africa and reserves the right to reject any material deemed inappropriate for publication. Responsibility for opinions expressed and for the accuracy of facts published rests solely with the individual authors. 

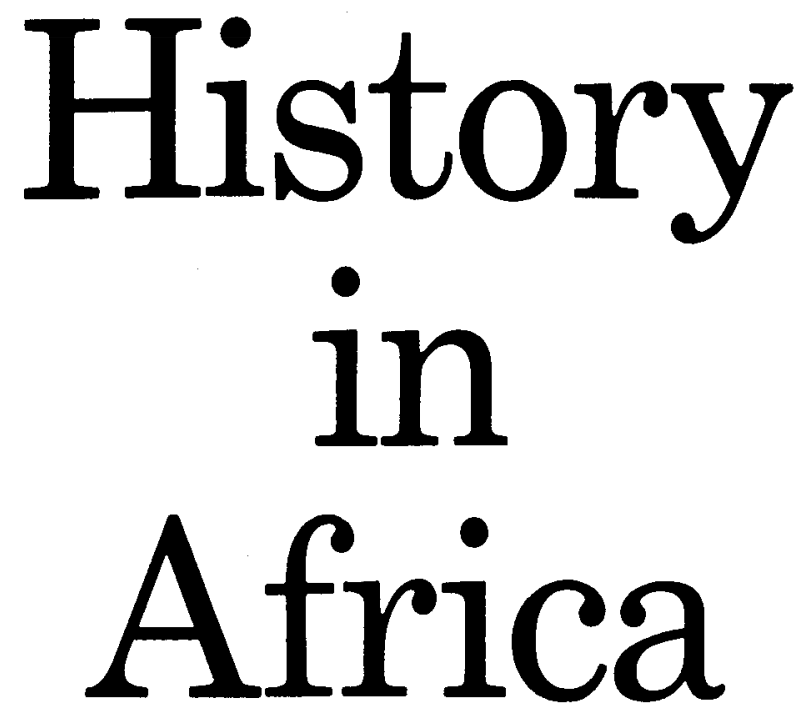

\title{
A JOURNAL OF METHOD
}

David Henige, Editor

\author{
AFRICAN STUDIES ASSOCIATION \\ Brandeis University
}

Waltham, Massachusetts 02154 
Copyright 1982

\section{African Studies Association}

All rights reserved

No part of this publication may be reproduced or transmitted in any form or by any means, including photocopy, recording, or any information storage and retrieval system, without permission in writing from the publisher. Any author has the right to republish his article in whole or in part without requesting permission from the association; others desiring permission to republish material should write to the association at 255 Kinsey Hall, University of California-Los Angeles, 405 Hilgard Avenue, Los Angeles, California 90024, U.S.A. 
History: in the end, you can never prove a thing

Robert Coover, The Universal

Baseball Association, Inc.,

J. Henry Waugh, Prop. 
CONTENTS

Theories and Facts: The Early Gothic Migrations

Thomas S. Bums

The Conquest That Never Was: Ghana and the Almoravids, 1076. I. The External Arabic Sources

David Conrad and Humphrey Fisher

The tompon-tany and the tompon-drano in the History

of Central and Western Madagascar

Finn Fuglestad

Written Sources and African History: A P1ea for the Primary Source. The Angola Manuscript Collection of Ferñao de Sousa

Beatrix Heintze

Documentary Research on Sub-Saharan Africa in Belgium Marcel d'Hertefelt

Ngundeng and the "Turuk:" Two Narratives Compared Douglas H. Johnson

Double Dutch? A Survey of Seventeenth-Century German Sources for West African History Adam Jones

Jean Barbot as a Source for the Slave Coast of West Africa Robin Law

Segeju and Daisũ: A Case Study of Evidence From Oral Tradition and Comparative Linguistics Derek Nurse

A Bio-Bibliography of F.D. Lugard

Thomas $P$. Ofcansky

Myth and History: The Malagasy Andriambahoaka and the Indonesian Legacy

$$
\text { Paul ottino }
$$


Fulfulde Literature in Arabic Script David Robinson

The Anti-Slave Trade Theme in Dahoman History: An

Examination of the Evidence David Ross

The Boundaries of History in Oral Performance Elizabeth Tonkin

English Bosman and Dutch Bosman: A Comparison of Texts--VII Albert van Dantaig

$285-302$

Can a B1ind Man Real1y know an Elephant? Lesson on the Limitations of Oral Tradition From Paul Irwin's Liptako Speaks

Donald $R$. Wright

Priorities and Opportunities for Research in Swaziland

AZan R. Booth

The Sacred Meadows: A Case Study of "Anthropologyland" vs. "Historyland"

Patricia Romero Curtin

Bibliographie ethographique de l'Afrique sub-Saharienne David Newbury

African History Research Program at the University of Trondheim Jarle Simensen

The Archives of the Gold Mines of Kilo-Moto Agayo Bakonzi

Africanist Archival Research in Brussels Carol Dickerman and David Northmup

A Further Note on the Amsterdam Notarial Records Adam Jones

The Archives of the Zone de Bulungu and the SousRegion du Kwilu (Region de Bandundu, Zaire): A Situation Report Robert Eugene Smith $371-376$

The National Archives of the Ivory Coast Ashton Wesley Welch $377-380$

Comparative Bibliography - 1982

$381-410$ 